\title{
Intrathecal Baclofen Infusion Pumps in the Treatment of Spasticity: A Retrospective Cohort Study in a Portuguese Centre
}

\author{
Bombas Perfusoras de Baclofeno Intratecal no \\ Tratamento da Espasticidade: Estudo de Coorte \\ Retrospetivo num Centro Português
}

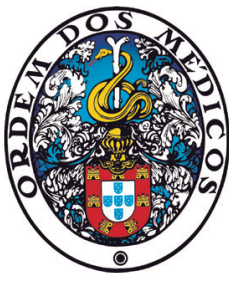

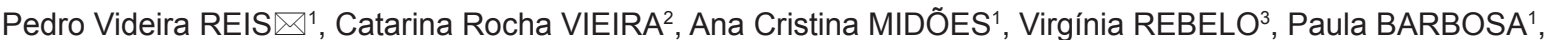 \\ Armanda GOMES ${ }^{1}$ \\ Acta Med Port 2019 Dec;32(12):754-759 - https://doi.org/10.20344/amp.10482
}

\section{ABSTRACT}

Introduction: Spasticity is a complex problem in patients with neurological disorders and may distress their quality of life. Intrathecal baclofen infusion pumps reduce spasticity with low doses and minimal side effects but are not free from complications. We aimed to evaluate the efficacy and safety of intrathecal baclofen infusion pumps as well as patients' satisfaction.

Material and Methods: Retrospective cohort study including all intrathecal baclofen infusion pumps placed up to December 2015 . Demographic characteristics, clinical diagnoses, date of placement or withdrawal/replacement of intrathecal baclofen infusion pumps, baclofen dosage and complications of intrathecal baclofen infusion pumps were collected. Assessments from the Ashworth and Penn's scales, Katz index and patients' global satisfaction were analysed.

Results: In 19 years we placed 251 intrathecal baclofen infusion pumps in 155 patients. The mean age was $41.1 \pm 15.8$ years. The most frequent conditions were: trauma (34\%), cerebral palsy $(14 \%)$, multiple sclerosis $(12 \%)$ and stroke $(12 \%)$. Eighty-five patients $(55 \%)$ required a second pump, and eleven $(7 \%)$ a third one. The lifetime of the first pump was $72(36-89)$ and the total follow-up time was $96(9-132)$ months. The causes of withdrawal/replacement were: battery failure $(57 \%)$, catheter migration/kinking $(24 \%)$, infection (14\%) and pump displacement/exteriorization (7\%). The complication rate was 0.21 events/month. There was a significant improvement in the Ashworth and Penn's scales after the placemen of intrathecal baclofen infusion pumps $(p<0.001$ for all diagnoses) and the patients were satisfied with the treatment.

Discussion: The incidence of complications was within range of other international studies despite our long follow-up time. Events per month, loss to follow-up, re-intervention rate, incidence of infection and mortality were similar to other studies.

Conclusion: Intrathecal baclofen infusion pumps are safe and effective in the treatment of spasticity. Infusion pumps provide a high level of satisfaction regarding treatment and quality of life.

Keywords: Baclofen/administration \& dosage; Baclofen/therapeutic use; Infusion Pumps, Implantable; Muscle Spasticity/drug therapy

\section{RESUMO}

Introdução: A espasticidade é um problema complexo em doentes com distúrbios neurológicos influenciando a sua qualidade de vida. As bombas perfusoras intratecais de baclofeno reduzem a espasticidade com doses baixas e efeitos laterais mínimos, mas não estão livres de complicações. Pretendemos avaliar a eficácia, segurança e satisfação dos doentes com bombas perfusoras intratecais de baclofeno.

Material e Métodos: Estudo de coorte retrospetivo, incluindo todas as bombas perfusoras intratecais de baclofeno colocadas até dezembro de 2015. Foram avaliadas as características demográficas, diagnósticos, data de colocação ou retirada/substituição e complicações das bombas perfusoras intratecais de baclofeno. Analisaram-se as escalas Ashworth, Penn, Katz e satisfação dos doentes. Resultados: Durante 19 anos colocaram-se 251 bombas perfusoras intratecais de baclofeno em 155 doentes. A idade média foi 41,1 $\pm 15,8$ anos. As patologias mais freqüentes foram: traumatismo (34\%), paralisia cerebral (14\%), esclerose múltipla (12\%) e acidente vascular cerebral (12\%). Oitenta e cinco doentes $(55 \%)$ precisaram de uma segunda e onze $(7 \%)$ de uma terceira bomba. A semi-vida da primeira bomba foi $72(36$ - 89) e o tempo total de seguimento $96(9$ - 132) meses. As causas de retirada/substituição foram: falha de bateria (57\%), migração/kinking do cateter (24\%), infeção (14\%) e deslocamento/exteriorização da bomba (7\%). A taxa de complicações foi 0,21 eventos/mês. Houve uma melhoria significativa nas escalas de Ashworth e Penn após colocação das bombas perfusoras intratecais de baclofeno ( $p<0,001$ para todos os diagnósticos) e os doentes ficaram satisfeitos com o tratamento.

Discussão: A incidência de complicações situou-se dentro do intervalo reportado por outros estudos internacionais, apesar do longo tempo de seguimento. Número de eventos por mês, perda de seguimento, taxas de re-intervenção ou infecção e mortalidade foram semelhantes a outros estudos.

Conclusão: As bombas perfusoras intratecais de baclofeno são seguras e eficazes no tratamento da espasticidade e oferecem um alto nível de satisfação quanto ao tratamento e qualidade de vida.

Palavras-chave: Baclofeno/administração e dosagem; Baclofen/uso terapêutico; Bombas de Infusão Implantáveis; Espasticidade Muscular/tratamento

\footnotetext{
1. Department of Anaesthesiology. Centro Hospitalar São João. Porto. Portugal.

2. Unidade de Saúde Familiar Camélias. Vila Nova de Gaia. Portugal.

3. Department of Psychiatry. Centro Hospitalar São João. Porto. Portugal.

$\triangle$ Autor correspondente: Pedro Videira Reis. pedrojreis@hotmail.com

Recebido: 02 de março de 2018 - Aceite: 17 de junho de 2019 | Copyright @ Ordem dos Médicos 2019
} 


\section{INTRODUCTION}

Spasticity is a complex problem that follows an upper motor neuron injury, affecting muscle tone and resistance to passive stretch, and is associated with hyperreflexia and muscle spasms. ${ }^{1}$ It is a consequence of numerous conditions of the central nervous system (CNS) such as traumatic brain injury (TBI), spinal cord injury (SCl), stroke, cerebral palsy (CP) and multiple sclerosis (MS). ${ }^{1}$ Spasticity may cause pain, discomfort and interfere with mobility. In addition to the physical consequences, patients often present emotional disturbances and may become dependent, which affects their quality of life. ${ }^{1}$

Various functional scales classify the severity of the disease. The Katz Index grades the patient as independent, partially dependent, and totally dependent, depending on the activities that can be accomplished before any treatment. The Ashworth and Modified Ashworth scales are based on the degree of muscle tone assessment while the Penn Scale is based on the frequency of muscle spasms. These scales range from 0 to 4 in accordance to the presence of more or less tonus or muscular spasms. These quantitative scales are not only used to assess the degree of spasticity, but also to evaluate treatment efficacy. ${ }^{2-17}$

Baclofen acts on $y$-Aminobutyric acid (GABA)-B receptors inhibiting the release of excitatory neurotransmitters and reducing spasticity. As a result of its low lipid solubility, oral baclofen barely crosses the blood brain barrier. Intrathecal administration reduces muscle tone with only $1 \%$ of the oral dose being required. A continuous administration is desirable as its half-life in cerebrospinal fluid (CSF) is only five hours and has limited dispersion. ${ }^{1}$ This is accomplished with infusion pumps (IPs) which have two components: a refillable reservoir connected to an intrathecal catheter and a lithium battery. The infusion rate and additional boluses can be programmed externally by radio telemetry. Before the placement of IPs, a test dose is performed with 50 or $100 \mu \mathrm{g}$ of intrathecal baclofen, followed by spasticity evaluation every 2 hours for $6-8$ hours. The test is positive if there is a 2 point reduction in the Ashworth or Modified Ashworth scale. ${ }^{2-18}$

Possible complications of IPs are surgical (infection, dehiscence); intrinsic pump failure (mechanical or battery failure, migration, occlusion, fracture or disconnection of the catheter); and human error (overdoses by mistake while programming doses or pump refills). These can lead to discontinuation of therapy, surgical removal of the pump, or, in rare cases, death. Prolonged administration causes down-regulation of receptors and the abrupt discontinuation may lead to withdrawal syndrome. Alarms decreased human errors and improved detection of mechanical problems. Technological evolution allowed its use in paediatric patients. $6,10,16,19-22$

Our Chronic Pain unit (CPU) is a national reference in the treatment of patients with spasticity. This study aimed to evaluate the efficacy and safety of IPs, their complications, as well as the patients' satisfaction with this treatment.

\section{MATERIAL AND METHODS}

Retrospective cohort study approved by the institutional ethics committee of our hospital including all patients with an implanted IP since 1997 until December 2015. Demographic characteristics, clinical diagnoses, date of placement or withdrawal/replacement of IPs and baclofen dosage in micrograms /day were collected. Assessments from the Ashworth and Penn's scales pre and post placement of IPs, Katz Index and patients' global satisfaction (numeric rating scale from 0 to 10,0 being very unsatisfied and 10 totally satisfied) were also analysed. All complications related to the IPs or intrathecal catheter were obtained until December 2015.

The histogram and the Kolmogorov-Smirnov tests were used to evaluate the distribution of ordinal and continuous variables. A descriptive analysis was used to summarize the results with the data being presented as mean \pm standard deviation (SD) or median and interquartile range (P25-P75). Dichotomic variables were analysed with the $X^{2}$ or Fisher tests and the continuous variables were analysed with the Mann-Whitney test, paired or independent $t$-test. A statistically significant $p$ was defined as $<0.05$.

\section{RESULTS}

In a total of 19 years (1997 - 2015), 251 IPs were placed in 155 patients, thus averaging 14 pumps per year. Table 1 presents patients' characteristics. The mean age was $41.1 \pm 15.8$ years, ranging from 7 to 77 years, with 14 patients $(9 \%)$ under 18 years old. There were no differences in age between genders $(p=0.79)$. The most frequent condition was trauma (TBI or SCI) with $34 \%$, followed by $\mathrm{CP}$ with $14 \%$, MS and stroke both with $12 \%$. The distribution of ages by clinical diagnoses is shown in Fig. 1. There was a

Table 1 - Patients' characteristics

\begin{tabular}{lc}
\hline & Total $(\mathbf{n}=\mathbf{1 5 5})$ \\
\hline Gender $-\mathrm{n}(\%)$ & $105(68)$ \\
- Male & $50(32)$ \\
- Female & $41.1 \pm 15.8$ \\
Age (years) - mean \pm standard deviation & \\
Clinical diagnosis - $\mathrm{n}(\%)$ & $53(34)$ \\
- Trauma & $22(14)$ \\
- Cerebral palsy & $19(12)$ \\
- Multiple sclerosis & $19(12)$ \\
- Stroke-related & $15(10)$ \\
- Neurodegenerative & $14(9)$ \\
- Inflammatory / Infectious & $13(8)$ \\
- Other & \\
Pump replacements - $\mathrm{n}(\%)$ & $85(55)$ \\
- Once & $11(7)$ \\
- Twice & $15(10)$ \\
Pump withdrawal without replacement - $\mathrm{n}(\%)$ & \\
Follow-up time (months) - median & $96(9-132)$ \\
(P25 - P75) & \\
Lifetime of 1st pump (months) - median & $72(36-89)$ \\
(P25 - P75) & \\
Intrathecal baclofen dose ( $\mu$ g/day) - median & $230(95-400)$ \\
(P25 - P75) &
\end{tabular}




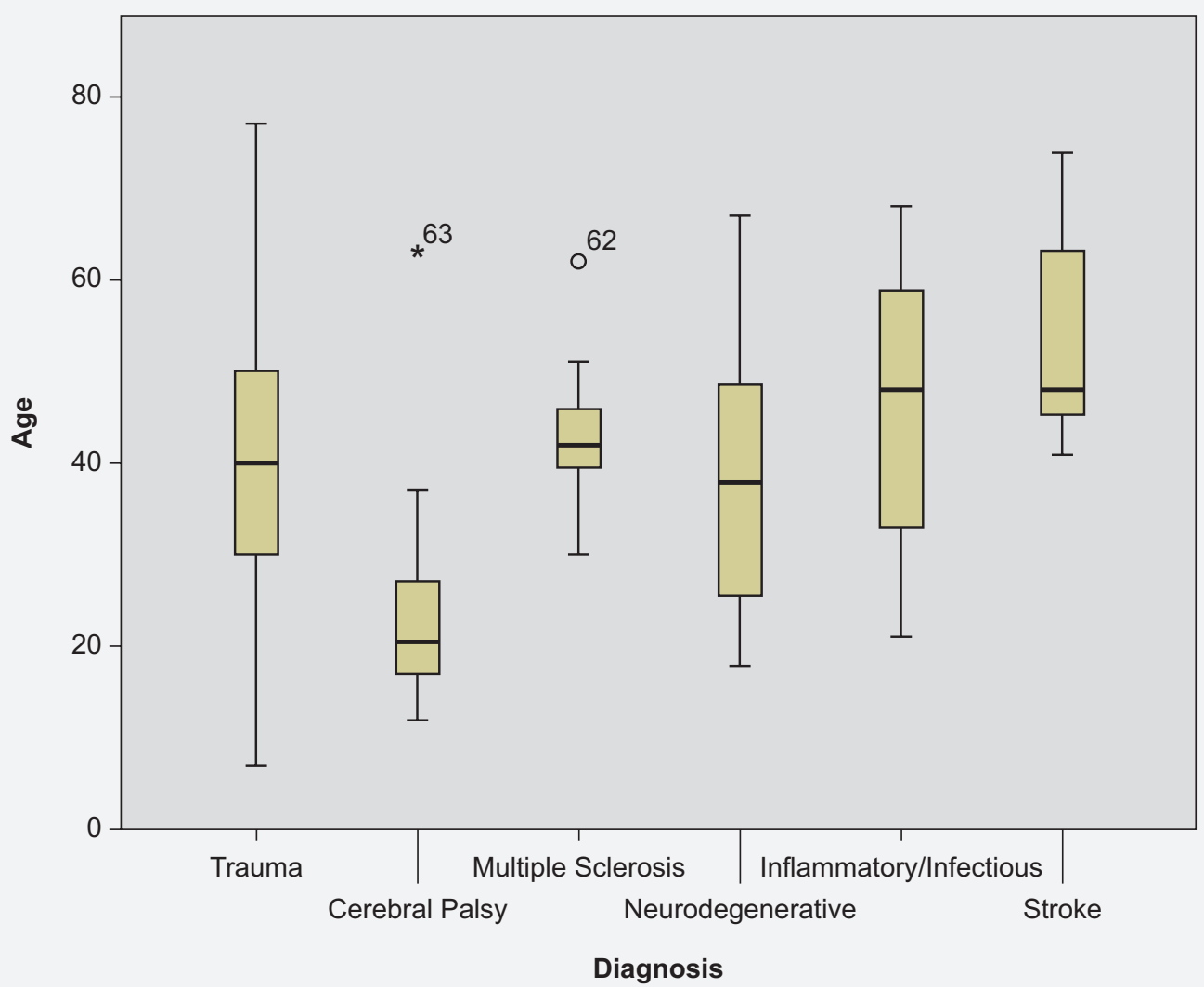

Figure 1 - Distribution of ages by diagnoses

statistically significant difference in age among patients with CP versus stroke $(p<0.001)$.

The invasive procedures of our CPU are performed in an operating room on a monthly basis, with patients being admitted the day before surgery. Our surgical team always includes two anaesthesiologists. Most pumps are placed under general anaesthesia. Antibiotic prophylaxis consists of intravenous cefazolin according to the institutional protocol.

A small incision between lumbar spinal processes, usually the L3 - L4 interspace, is made and the subarachnoid space is punctured with a $14 \mathrm{G}$ Tuohy needle, through which the guide wire catheter is introduced and advanced under radiological control until the $\mathrm{T} 10$ level. After removing the guide wire and with the catheter in the desired location, the needle is withdrawn. The catheter is then tunnelled subcutaneously from the lumbar region to the abdominal wall and connected to the IP when fully filled by CSF. It is fixed to the paravertebral muscles with a tense U-point to reduce the risk of CSF leakage. We used the Medtronic SyncroMed EL up to 2005 and SyncroMed II thereafter. The InDura intrathecal catheter (Model 8709SC) was used up to 2011, and was replaced by the Ascenda intrathecal catheter (Model 8780 - 8781) thereafter.

The starting dose of baclofen infusion is $50 \mu \mathrm{g} /$ day except in paediatric patients where it starts at $25 \mu \mathrm{g} /$ day. During postoperative hospitalization, the patient is re-evaluated daily and the dose is adjusted according to their spasticity. Subsequently, the patient is also re-assessed from time to time in the Outpatient Clinic, as well as during the pump refills. Continuous infusion with fixed dose is prescribed, total daily dose being $230(95-400) \mu \mathrm{g} /$ day, with a minimum dose of 25 and a maximum dose of $2130 \mu \mathrm{g} / \mathrm{day}$.

During the follow-up period (1997-2015), 55\% ( $n=85)$ required a second and $7 \%(n=11)$ a third IP. In 15 patients $(10 \%)$ the IP was removed without replacement. The longevity of the patients' first pump was $72(36-89)$ with a maximum of 144 months. The average follow-up time was $96(9-132)$ months. Table 2 and Fig. 2 show the causes of withdrawal or replacement of the IPs, as well as the follow-up time until complications.

Excluding battery replacements that required interventions within the predicted time, there was a total of $48 \mathrm{com}$ plications in 251 procedures (an incidence of 19\%). Dividing

Table 2 - Causes of pump withdrawal or replacement and follow-up time until complications

\begin{tabular}{lc}
\hline & Total $(\mathbf{n}=\mathbf{1 1 1})$ \\
\hline Reason for withdrawal / replacement & $\mathrm{n}(\%)$ \\
- Battery & $63(57)$ \\
- Catheter (migration or kinking) & $24(22)$ \\
- Infection & $16(14)$ \\
- Pump displacement / exteriorization & $8(7)$ \\
Months until battery replacement - median & $84.5(81-102)$ \\
(P25 - P75) & $49(13-78)$ \\
Months until infection - median (P25 - P75) & \\
Months until catheter / pump complications - & $70.5(15-86)$ \\
median (P25 - P75) &
\end{tabular}




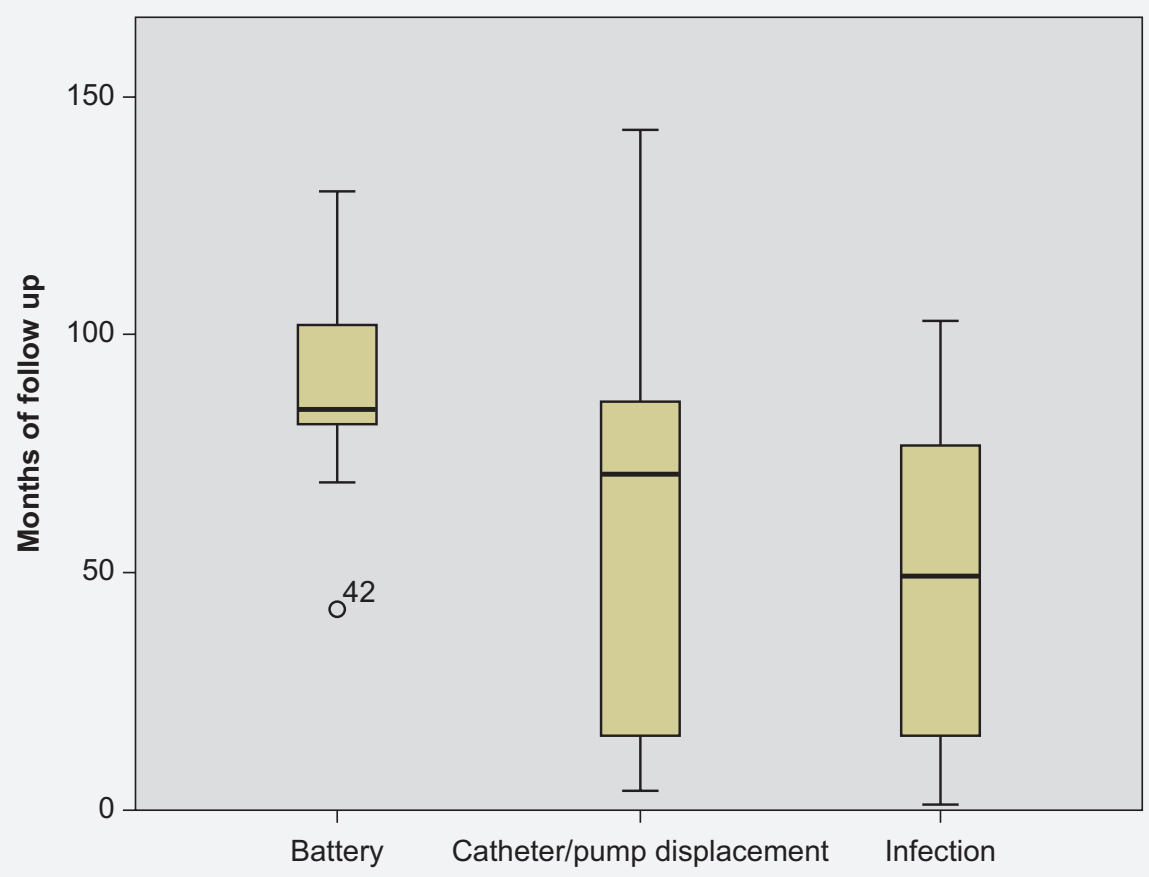

Cause of replacement or withdrawal

Figure 2 - Follow-up time up to the first complication in months

the number of complications by the number of months of follow-up (228), we found a rate of 0.21 events per month. Three rare events occurred: one CSF fistula demanding blood patch, one pump rotation inside a surgical pocket requiring relocation, and one abrupt baclofen withdrawal syndrome due to a catheter problem. It should be noted that the fistula event was prior to the insertion of the $U$-point for catheter fixation.

There were 10 patients lost to follow-up (6\%) and 22 deaths (14\%) from non-related causes. These patients were not different from all the others in terms of age, gender, preoperative diagnoses, complications or follow-up time. No patient had any side effects directly due to intrathecal use of baclofen or neurological deficits as a result of this treatment.

We measured the pre-operative Katz Index in 107 patients, and $43 \%(n=46)$ were totally dependent, $39 \%$ $(n=42)$ partially dependent and $18 \%(n=19)$ independent. There were no significant differences in age, sex and diagnoses between groups. Regarding the Ashworth and Penn functional scales, there was a significant improvement comparing the pre [Ash and Penn $4(3-4)]$ to the postoperative [Ash $1(1-2)$ and Penn $1(0-1)$ ], $p<0.001$ for all subgroups of diagnoses (Fig. 3). All of them were satisfied with the treatment (score $\geq 5$ ), as shown in Fig. 4 .

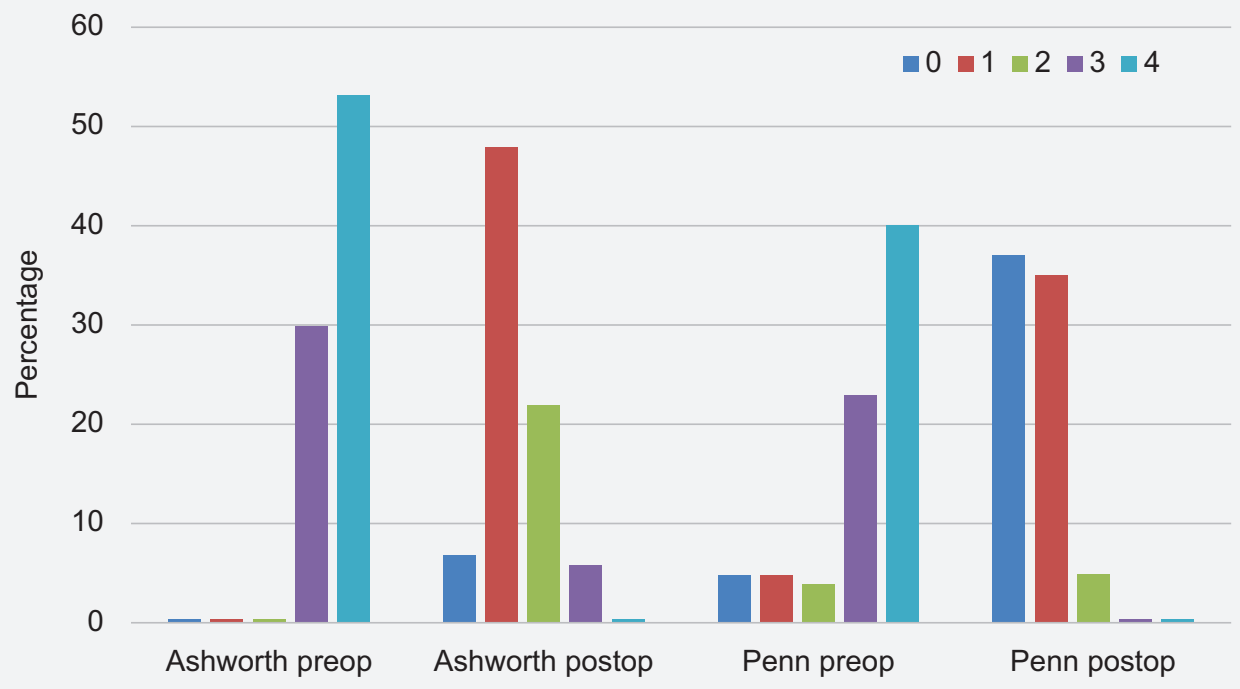

Figure 3 - Variation of the Ashworth and Penn functional scales between preoperative (preop) and postoperative period (postop), $p<0.001$ 


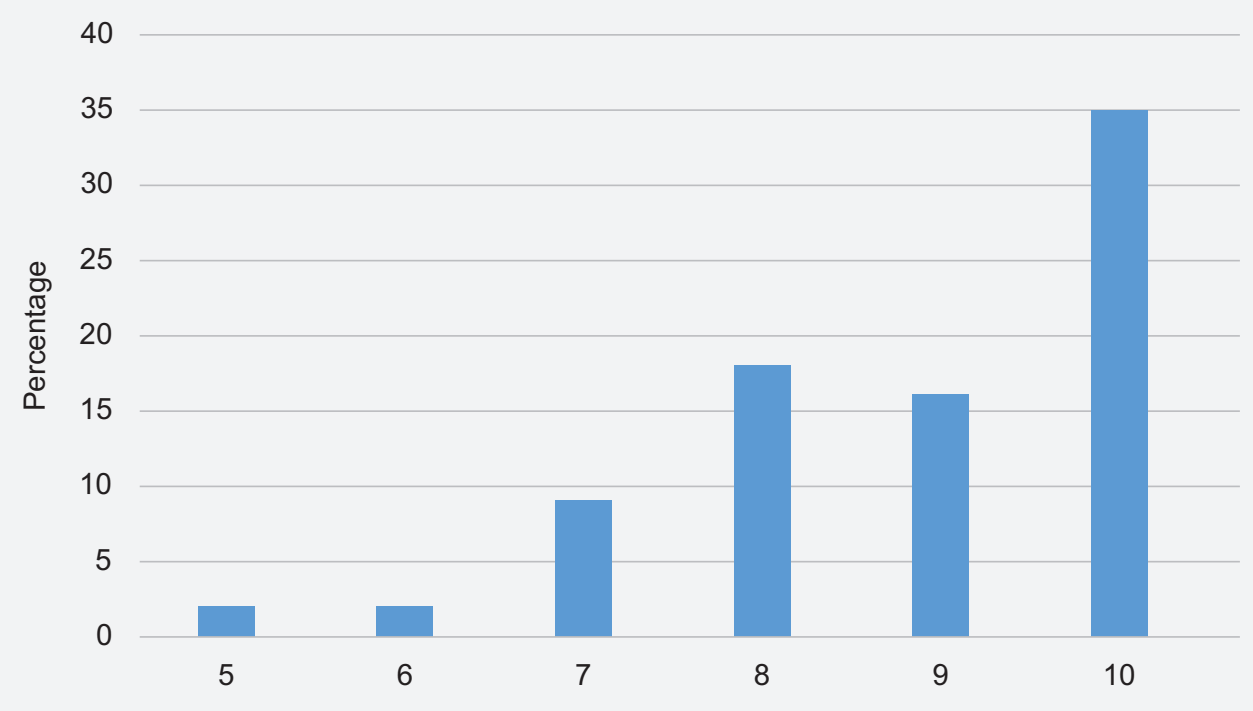

Figure 4 - Global patient satisfaction with the treatment $(1-10)$. All patients were satisfied with the treatment (all answers $\geq 5)$.

\section{DISCUSSION}

During the 19 years of follow-up, $19 \%$ of procedures had complications (48/251). In other studies, the incidence of serious complications that required re-intervention varied between $25 \%$ and $37 \%$, despite shorter follow-up times. ${ }^{20-23}$ We had an average of 0.21 events per month, very similar to the 0.23 obtained by Borrini et al..$^{19}$

According to Taira et al, the incidence of infection can vary between $0.8 \%$ and $15 \% .{ }^{22}$ We obtained an infection rate of $6.4 \%(16 / 251)$, less than the $26 \%$ of Borrini et al. ${ }^{19}$ In the Motta et al study, carried out in a paediatric population, the subfascial implantation had a lower rate of infection compared with subcutaneous implantation: 3.6 vs $20.1 \%$, $p<0.001 .{ }^{21}$ Globally, the rate of infection in that study was $9.3 \% .{ }^{21}$ Some other studies ${ }^{1}$ mention a higher rate of infection in patients with $\mathrm{CP}$, which was not the case in our study $\left(X^{2}=0.703, p=0.402\right)$. Although the subfascial technique appears to have a lower rate of complications such as dehiscence or infections in the literature, we found a rate that is lower compared to most of those studies. ${ }^{21}$ Type of infection, pathogenic agent and established treatment were already described by Malheiro et al regarding complications that occurred until May 2014. ${ }^{24}$ Antibiotic prophylaxis with $2 \mathrm{~g}$ of intravenous cefazolin is recommended by national and institutional guidelines for surgical site infection prevention and may explain our results. ${ }^{25}$

Problems related to the catheter occurred in $9.6 \%$ of cases (24/251). In a summarized chart from Taira et al, we can see rates as different as $6 \%$ to $75 \% .{ }^{22}$ Before 2011 , with first generation catheters, the study of its correct positioning or functioning could be done by simple radiography since it was radiopaque and there were those who defended periodic imaging as a way to detect early problems ${ }^{21}$ Currently, the new generation catheters are incompressible (anti-kinking system), but not radiopaque, requiring magnetic resonance evaluation. For this reason, at the time of placement, it is necessary to maintain the guide wire inside the catheter to allow its intraoperative visualization with fluoroscopy. When the catheter reaches the desired level, the guide wire is removed, as well as the needle..$^{18}$

In our study, 22 patients died during the follow-up period corresponding to a mortality rate of $14 \%$. In literature, this rate varies between 0 and $21 \%$. ${ }^{18,20,21,26}$ This difference can be explained by the inclusion of different conditions and different follow-up times.

According to Albright et al, teams dedicated to IPs must carry out a minimum of 10 annual procedures to maintain their skills. ${ }^{22}$ In our CPU, we perform an average of 14 procedures per year. The $6 \%$ loss to follow-up is essentially due to patients changing address. We follow IPs implanted in our and in other medical centres in Europe.

Like in other investigations, this study demonstrated the efficacy of IPs in the treatment of spasticity, through the improvement of muscular tonus and the number of spasms. $2,7,14,15,20$ The reduction of the Ashworth and Penn scales from pre to post-surgery was respectively $2(2-3)$ and $3(2-3), p<0.001$ for both, in line with the literature. This reduction was statistically significant in all the diagnostic subgroups with $p<0.001$.

This study also tried to measure the therapeutic impact of IPs in the quality of life using a global satisfaction index. All patients confirmed improvements with the IPs ( $\geq 5$ score) and almost half $(44.6 \%)$ rated their quality of life and everyday activities with the level 10 . It should be noted that $84 \%$ presented a level of satisfaction $\geq 8$, similar to the study of Mathur et al. ${ }^{2}$

Most patients showed a therapeutic control with a dose of $230(95-400) \mu \mathrm{g} /$ day of baclofen. These doses are similar to those described in the literature. . $^{2-5,7,9,11-17,19,22,26-29}$

The cost-benefit analysis carried out by Saulino et al demonstrated a high initial cost with the IPs but with mitigation and even long-term benefit. ${ }^{30}$ The transition from a higher cost to a lower one would be around the second year after implantation, which corresponds in our study to 
a significant benefit since the follow-up time is long (median of 96 months). It is expected that the improvement in physical and mental well-being of patients promotes a lower number of complications, such as pressure sores or venous thrombosis, leading to a lower number of hospitalizations, thus making IPs cost-efficient.

The limitations of our study are related to the fact that it is retrospective and only focuses on major complications that required surgical intervention. It was not possible to verify the existence of adjuvant therapies in the treatment of spasticity, such as physical therapy, orthosis or other drugs that can influence outcomes. It would be interesting to evaluate its efficacy in different muscular groups, such as upper and lower limbs but we did not have that data available for analysis.

\section{CONCLUSION}

The results of this study demonstrate that IPs are a safe, valid and effective therapy in the treatment of spasticity.

\section{REFERENCES}

1. Ammar A, Ughratdar I, Sivakumar G, Vloeberghs $\mathrm{MH}$. Intrathecal baclofen therapy—how we do it. J Neurosurg Pediatr. 2012;10:439-44.

2. Mathur SN, Chu SK, McCormick Z, Chang Chien GC, Marciniak CM. Long-term intrathecal baclofen: outcomes after more than 10 years of treatment. PM R. 2014;6:506-13.

3. Khurana SR, Garg DS. Spasticity and the use of intrathecal baclofen in patients with spinal cord injury. Phys Med Rehabil Clin N Am. 2014;25:655-69.

4. Veiros IM, Martins F. O baclofeno intratecal no tratamento da espasticidade. Acta Med Port. 2006;19:217-24.

5. Heetla HW, Staal MJ, Proost JH, van Laar T. Clinical relevance of pharmacological and physiological data in intrathecal baclofen therapy. Arch Phys Med Rehabil. 2014;95:2199-206.

6. Bethoux F, Boulis N, McClelland S, Willis MA, Hussain M, Machado A, et al. Use of intrathecal baclofen for treatment of severe spasticity in selected patients with motor neuron disease. Neurorehabil Neural Repair. 2013;27:828-33.

7. Natale M, D'Oria S, Nero VV, Squillante E, Gentile M, Rotondo M. Longterm effects of intrathecal baclofen in multiple sclerosis. Clin Neurol Neurosurg. 2016;143:121-5.

8. Erwin A, Gudesblatt M, Bethoux F, Bennett SE, Koelbel S, Plunkett $\mathrm{R}$, et al. Intrathecal baclofen in multiple sclerosis: too little, too late? Multiple sclerosis. 2011;17:623-9.

9. Ordia JI, Fischer E, Adamski E, Spatz EL. Continuous intrathecal baclofen infusion delivered by a programmable pump for the treatment of severe spasticity following traumatic brain injury. Neuromodulation. 2002;5:103-7.

10. Francisco GE, Saulino MF, Yablon SA, Turner M. Intrathecal baclofen therapy: an update. PM R. 2009;1:852-8.

11. Clearfield JS, Nelson ME, McGuire J, Rein LE, Tarima S. Intrathecal baclofen dosing regimens: a retrospective chart review. Neuromodulation. 2016;19:642-9.

12. Margetis K, Korfias S, Boutos N, Gatzonis S, Themistocleous M, Siatouni A, et al. Intrathecal baclofen therapy for the symptomatic treatment of hereditary spastic paraplegia. Clin Neurol Neurosurg. 2014;123:142-5.

13. Margetis K, Korfias SI, Gatzonis S, Boutos N, Stranjalis G, Boviatsis E, et al. Intrathecal baclofen associated with improvement of consciousness disorders in spasticity patients. Neuromodulation. 2014;17:699-704.

14. Ordia Jl, Fischer E, Adamski E, Chagnon KG, Spatz EL. Continuous intrathecal baclofen infusion by a programmable pump in 131 consecutive patients with severe spasticity of spinal origin Neuromodulation. 2002;5:16-24.

15. Mclntyre A, Mays R, Mehta S, Janzen S, Townson A, Hsieh J, et al. Examining the effectiveness of intrathecal baclofen on spasticity in individuals with chronic spinal cord injury: a systematic review. J Spinal Cord Med. 2014;37:11-8.

16. Stetkarova I, Brabec K, Vasko P, Mencl L. Intrathecal baclofen in spinal spasticity: frequency and severity of withdrawal syndrome. Pain
Infusion pumps provide a high level of satisfaction in relation to the type of treatment and the patient's quality of life.

\section{PROTECTION OF HUMANS AND ANIMALS}

The authors declare that the procedures were followed according to the regulations established by the Clinical Research and Ethics Committee and to the Helsinki Declaration of the World Medical Association.

\section{DATA CONFIDENTIALITY}

The authors declare having followed the protocols in use at their working center regarding patients' data publication.

\section{CONFLICTS OF INTEREST}

All authors contributed to the study and declare no conflicts of interest.

\section{FUNDING SOURCES}

No funds were used for this work.

Physician. 2015;18:E633-41.

17. McCormick ZL, Chu SK, Binler D, Neudorf D, Mathur SN, Lee J, et al. Intrathecal versus oral baclofen: a matched dohort study of spasticity, pain, sleep, fatigue, and quality of life. PM R. 2016;8:553-62.

18. Scannell B, Yaszay B. Scoliosis, spinal fusion, and intrathecal baclofen pump implantation. Phys Med Rehabil Clin N Am. 2015;26:79-88.

19. Borrini L, Bensmail D, Thiebaut JB, Hugeron C, Rech C, Jourdan C Occurrence of adverse events in long-term intrathecal baclofen infusion: a 1-year follow-up study of 158 adults. Arch Phys Med Rehabil. 2014;95:1032-8.

20. Walter M, Altermatt S, Furrer C, Meyer-Heim A. Intrathecal baclofen therapy in children with severe spasticity: outcome and complications. Dev Neurorehabil. 2014;17:368-74.

21. Motta F, Antonello CE. Analysis of complications in 430 consecutive pediatric patients treated with intrathecal baclofen therapy: 14-year experience. J Neurosurg Pediatr. 2014;13:301-6.

22. Taira T, Ueta T, Katayama $Y$, Kimizuka M, Nemoto A, Mizusawa H, et al. Rate of complications among the recipients of intrathecal baclofen pump in Japan: a multicenter study. Neuromodulation. 2013;16:266-72.

23. Thakur SK, Rubin BA, Harter DH. Long-term follow-up for lumbar intrathecal baclofen catheters placed using the paraspinal subfascial technique. J Neurosurg Pediatr. 2016;17:357-60.

24. Malheiro L, Gomes A, Barbosa P, Santos L, Sarmento A. Infectious complications of intrathecal drug administration systems for spasticity and dhronic pain: 145 patients from a tertiary care center. Neuromodulation. 2015;18:421-7.

25. Paiva JA, Uva AS, Pina E, Alves V. Profilaxia antibiótica cirúrgica na criança e no adulto. Norma da Direcção-Geral da Saúde n 031/2013 de 31/12/2013. Lisboa: Direcção Geral da Saúde; 2013.

26. Draulans N, Vermeersch K, Degraeuwe B, Meurrens T, Peers K Nuttin B, et al. Intrathecal baclofen in multiple sclerosis and spinal cord injury: complications and long-term dosage evolution. Clin Rehabil. 2013;27:1137-43.

27. Wang ZM, Law JH, King NK, Rajeswaran DK, Soh S, Rao JP, et al. Treatment of severe, disabling spasticity with continuous intrathecal baclofen therapy following acquired brain injury: the experience of a tertiary institution in Singapore. Singapore Med J. 2016;57:8-12.

28. Dressler D, Berweck S, Chatzikalfas A, Ebke M, Frank B, Hesse S, et al. Intrathecal Baclofen therapy in Germany: Proceedings of the IABInterdisciplinary Working Group for Movement Disorders Consensus Meeting. J Neural Transm. 2015;122:1573-9.

29. Al-Khodairy AT, Wicky G, Nicolo D, Vuadens P. Influence of intrathecal baclofen on the level of consciousness and mental functions after extremely severe traumatic brain injury: brief report. Brain Inj. 2015;29:527-32.

30. Saulino M, Guillemette S, Leier J, Hinnenthal J. Medical cost impact of intrathecal baclofen therapy for severe spasticity. Neuromodulation. 2015;18:141-9. 